\title{
Article \\ Sediment Transport Management Using the Planned Construction of the Lower Vistula Cascade as an Example
}

\author{
Jarosław Biegowski ${ }^{1, *}$, Małgorzata Robakiewicz ${ }^{1}$, ${\text { Krzysztof } \text { Woś }^{2,3} \text { and Krzysztof Wrzosek }}^{2,4}(\mathbb{D}$ \\ 1 Institute of Hydro-Engineering, Polish Academy of Sciences, Kościerska 7, 80-328 Gdańsk, Poland; \\ marob@ibwpan.gda.pl \\ 2 State Water Holding Polish Waters, Żelazna 59a, 00-848 Warszawa, Poland; \\ krzysztof.wos@wody.gov.pl (K.W.); krzysztof.wrzosek@wody.gov.pl (K.W.) \\ 3 Faculty of Maritime Economy and Transport Systems, Maritime University of Szczecin, Wały Chrobrego 1-2, \\ 70-500 Szczecin, Poland \\ 4 Faculty of Building Services, Hydro and Environmental Engineering, Warsaw University of Technology, \\ Nowowiejska 20, 00-653 Warszawa, Poland \\ * Correspondence: jarbieg@ibwpan.gda.pl
}

Citation: Biegowski, J.; Robakiewicz, M.; Woś, K.; Wrzosek, K. Sediment Transport Management Using the Planned Construction of the Lower Vistula Cascade as an Example. Energies 2022, 15, 1689. https:// doi.org/10.3390/en15051689

Academic Editor: João Carlos de Campos Henriques

Received: 13 December 2021 Accepted: 19 February 2022 Published: 24 February 2022

Publisher's Note: MDPI stays neutral with regard to jurisdictional claims in published maps and institutional affiliations.

Copyright: (C) 2022 by the authors. Licensee MDPI, Basel, Switzerland. This article is an open access article distributed under the terms and conditions of the Creative Commons Attribution (CC BY) license (https:// creativecommons.org/licenses/by/ $4.0 /)$.

\begin{abstract}
Construction of the Włocławek Barrage on the Vistula River in 1970 became an important source of energy; however, it discontinued sediment transport in the Vistula River. This phenomenon resulted in accumulation before and erosion below the barrage; a similar problem can be expected due to the planned construction of the Lower Vistula Cascade. This study is dedicated to finding an effective and feasible solution to sediment transport management, acceptable to a wide group of users (e.g., navigation, energy producers, and ecologists). A numerical 1D model was applied to carry out analysis of hydrodynamics and sediment transport in the river section from Włocławek Barrage to the Vistula River mouth in the Baltic Sea. For calibration, historical data describing the accumulation and erosion created by the Włocławek Barrage were used. The proposed model allowed incorporation of new barrages chronologically, in accordance with the proposed time schedules. Analysis was carried out in a 50-year horizon, using a set of historical flow data. For sediment flushing, it was proposed to use natural flooding events exceeding $\mathrm{Q}_{10 \%}$ discharge and to control sediment management of the adjacent barrages. To use this method in practice requires verification.
\end{abstract}

Keywords: hydropower; Vistula River; water dam; barrages; sediment management; inland waterways; economic analysis

\section{Introduction}

Planning the construction of a cascade of barrages is a complex process in which different interests and requirements of water users must be considered. It is often very difficult to incorporate all requirements for the investment. However, disregard of them at the design stage may lead to significant problems during operation and, at a later stage, generate high costs allocated to its improvement. The transport of sediment, or generally the management of the sediment and its impact on the investment, is one such problem to be solved.

As a result of barrage construction, the sediment transport is discontinued, which causes accumulation of sediments in the upper part of the dam reservoir and erosion below it. The costs incurred to minimize the negative effects may be equivalent to the costs spent on a barrage construction [1]. Sediment transport was interrupted after the construction of the Włocławek Barrage on the Vistula River in 1970 (Figure 1). Due to this fact, accumulation in the Włocławek reservoir is $2 \times 10^{6} \mathrm{~m}^{3} /$ year, which is $0.5 \%$ of its initial volume. Erosion below the dam, reaching $4 \mathrm{~m}$ at bottom and $40-50 \mathrm{~km}$ in length, threatens the stability of the construction [2-4]. These problems result mainly from the fact that the Włocławek Barrage was designed to operate in a cascade of 7-9 objects [2-5]. 
The planned successive stages of the cascade were to have full hydrodynamic support, which would have resulted in the complete retention of the sediment in the area with a cascade [6-9]. Unfortunately, the cascade was never built, and the Włocławek Barrage has operated contrary to the design for over 50 years. The resumption of work on the design of the Lower Vistula Cascade was the main reason for conducting research on sediment transport in the proposed cascade. The aim of this study was to find a solution to maintain the continuity of the sediment transport. For a lowland river, it is possible to artificially maintain the continuity of the sediment flow by transporting the sediment by barges, pumping the sediment using a system of pipelines, or flushing with the passing flood [10]. The expected impact of the planned cascade reaches $266 \mathrm{~km}$ of the river section; to solve the problem of sediment transport, the possibility of using a flushing process was considered.

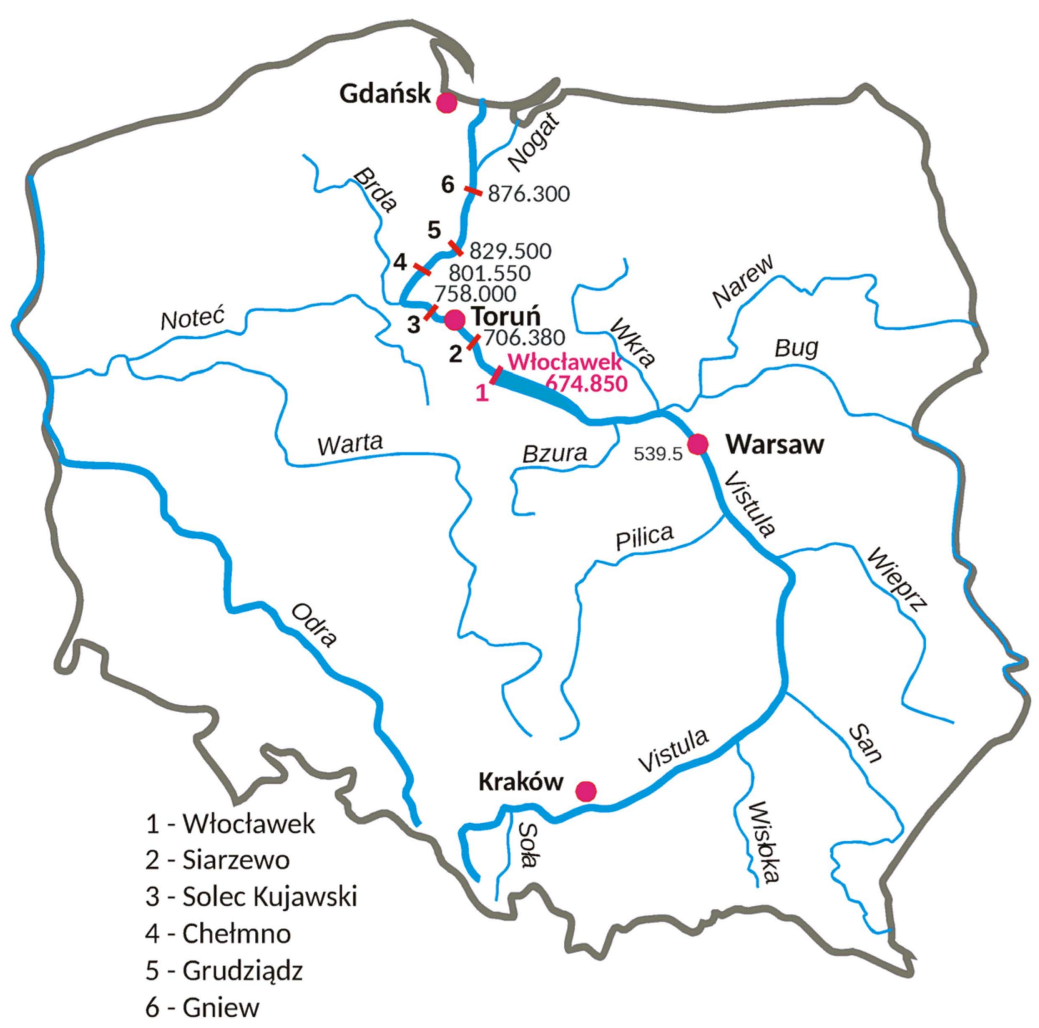

Figure 1. Location of the Włoclawek Barrage and proposed locations for further barrages (from [11]).

\section{Materials and Methods}

Numerous proposals for the Lower Vistula Cascades have been discussed since the end of the Second World War [6-8]. At first, Włocławek Barrage was put into operation in 1970. In the following years, it was planned to build barrages above and below Włocławek, but these plans were never implemented. The increasing problems with the stability of the Włocławek Barrage force us to undertake action to construct subsequent barrages. However, this is not the main reason why the construction of the Lower Vistula Cascade is currently being considered.

The changing climate and the country's needs and ongoing transformations in the energy sector have created new threats and challenges, which require action to mitigate the potential risks associated with flooding, drought, and the lack of sufficient and stable energy sources, which is an overriding social interest. The Lower Vistula Cascade is also part of the plans to adapt the Vistula River to waterways of international importance. In accordance with the AGN convention, it is planned to connect the Port of Gdansk with the Black Sea. Outside the Polish section of the planned International Waterway E-40, i.e., the Port of Gdańsk-Brest, the remaining route from Brest to the Black Sea is already built 
and ready to carry out water transport. On the Polish section of the international waterway, the construction of barrages is planned, which will be equipped with hydroelectric power plants.

Currently, only the flow-through operation of these power plants is envisaged; if necessary, the cascade can be used for pumped-storage conditions, which will further contribute to the stability of the energy system. Such work would be possible, but under strictly defined operating conditions, to not cause degradation of the natural environment.

In view of the many needs in the field of water management, inland navigation, and energy, every aspect contributing to the safe and proper operation of water structures is of great importance; these include ensuring the continuity of the sediment flow.

As part of the adaptation of the Vistula River to the IV class of the waterway, it is planned to construct 13 water barrages (not including the existing SW Włocławek) on the section from Gdańsk to Dęblin. Currently, the concept of building five barrages below Włocławek is being considered $[6-9,12,13]$. The presented work continues the research conducted by DHV [11,14] where a hydrodynamic model was calibrated for the flow parameters using bathymetry profiles. Extension of the mentioned earlier work consists of detailed analysis of the bathymetry changes due to the construction of the barrage, impact of the construction schedule, and searching for a method to minimize the cascade impact on sediment transport. The general characteristics of barrages are given in Table 1.

Table 1. Characteristics of the barrages included in the planned Lower Vistula Cascade.

\begin{tabular}{cccccc}
\hline Location & $\begin{array}{c}\text { Millage of } \\
\text { the River } \\
{[\mathbf{k m}]}\end{array}$ & $\begin{array}{c}\text { Damming } \\
\text { Level } \\
{[\mathbf{m} . \mathbf{a . s . 1}]}\end{array}$ & $\begin{array}{c}\text { Damming } \\
\text { Height [m] }\end{array}$ & $\begin{array}{c}\text { Installed } \\
\text { Power [MW] }\end{array}$ & $\begin{array}{c}\text { Average Annual } \\
\text { Energy } \\
\text { Production } \\
\text { [GWh] }\end{array}$ \\
\hline Włocławek & 674.85 & 57.30 & 8.80 & 160 & 700.0 \\
\hline Siarzewo & 706.38 & 46.00 & 8.50 & 70 & 384.0 \\
\hline $\begin{array}{c}\text { Solec } \\
\text { Kujawski }\end{array}$ & 758.00 & 37.50 & 8,50 & 79 & 379.2 \\
\hline Chełmno & 801.55 & 29.00 & 7.00 & 68 & 326.4 \\
\hline Grudziądz & 829.50 & 22.00 & 7.00 & 56.5 & 271.2 \\
\hline Gniew & 876.30 & 15.00 & 7.20 & 76 & 364.8 \\
\hline
\end{tabular}

Four scenarios of the cascade construction time schedule (Table 2), as well as the impact of the planned investment on erosion and sediment accumulation over the period of 50 years, i.e., from 2028 to 2078 were considered. As a comparative scenario (Scenario 0-S0), calculation without barrages was carried out.

Table 2. Proposed time schedule for barrages construction.

\begin{tabular}{ccccc}
\hline Location & $\begin{array}{c}\text { Scenario I } \\
\text { (SI) }\end{array}$ & $\begin{array}{c}\text { Scenario II } \\
\text { (SII) }\end{array}$ & $\begin{array}{c}\text { Scenario III } \\
\text { (SIII) }\end{array}$ & $\begin{array}{c}\text { Scenario IV } \\
\text { (SIV) }\end{array}$ \\
\hline Włocławek & 1970 & 1970 & 1970 & 1970 \\
\hline Siarzewo & 2028 & 2028 & 2028 & 2028 \\
\hline Solec Kujawski & 2034 & 2052 & 2034 & 2040 \\
\hline Chełmno & 2040 & 2046 & 2034 & 2040 \\
\hline Grudziądz & 2046 & 2040 & 2040 & 2034 \\
\hline Gniew & 2052 & 2034 & 2040 & 2034 \\
\hline
\end{tabular}

Each of the proposed scenarios, assumed the construction of the Siarzewo Barrage to be the first. This solution will ensure safe stability of the Włocławek Barrage. The aim of 
the analysis was to indicate the most favorable construction schedule due to the sediment transport within the planned cascade. The SII scenario is the least favorable because the Siarzewo Barrage would not be supported by the next barrage for a long period of time. However, from the navigation point of view, this is the most preferred scenario, allowing the lower section of the Vistula be navigable and ready to transport goods from the ports of Gdańsk and Gdynia. It should also be noted that the Gniew Barrage is significantly distant from the Vistula River mouth (called Ujście), about $64 \mathrm{~km}$, which may cause problems with severe bottom erosion below. This phenomenon will have a negative impact on navigation in this river section. The results of the analysis for the SII scenario are presented below.

The Vistula River is the largest river discharging into the Baltic Sea. The average annual flow through the Włocławek Barrage cross-section is $921 \mathrm{~m}^{3} / \mathrm{s}$, while at the outlet to the Baltic Sea (Tczew cross-section) the average discharge reaches $1046 \mathrm{~m}^{3} / \mathrm{s}$. There are no significant tributaries between Włocławek and the Baltic Sea, which allows us to assume, with some simplification, that the flow does not change along the whole section. To simulate the 50-year exploitation period of the cascade, daily measurements of the flow through the Włocławek Barrage during a period of 10 years (1 January 2005-31 December $2014[11,14])$, were used. During these 10 years, there were long periods of low flows and intense floods. The intensification of extreme conditions, i.e., droughts and floods, is related to the observed climate changes. The adoption of the chosen period of historical measurements, to some extent, presents the expected consequence of changing climate. To obtain a sufficiently long time series, the historical flows were repeated five times, analogous to [11,14], obtaining the adopted series for scenario analysis (from 1 January 2028 to 31 December 2077, Figure 2).

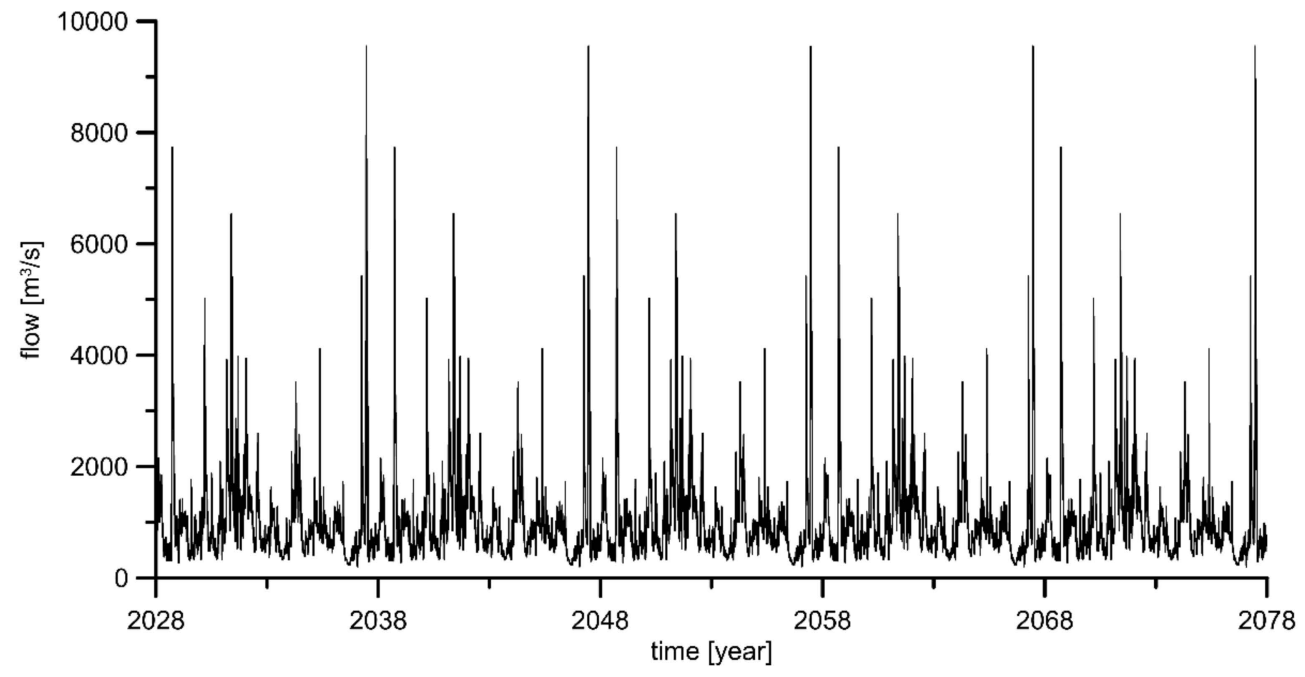

Figure 2. The change in the volume of flow through Włocławek Barrage in the period 1 January 2028-31 December 2078 adopted for the scenario analysis.

The impact of the cascade was tested for the characteristic flows given in Table 3. The parameters of the characteristic flows were determined for a period of 30 years, i.e., 1 January 1985-31 December 2015, using the daily records in Włocławek. The characteristic SNQ flow describes the average flow from the minimum annual flows, SSQ flow describes the average flow from the average annual flows, while flows $\mathrm{Q}_{50 \%}, \mathrm{Q}_{10 \%}, \mathrm{Q}_{1 \%}$, and $\mathrm{Q}_{0.2 \%}$ describe the flows with a given probability of occurrence determined using a Pearson type III distribution [15]. 
Table 3. Flow characteristics at the Włocławek water gauge (SNQ-average from the lowest annual flows, SSQ - average from annual averages, $\mathrm{Q}_{50 \%}$-maximum once every two years, $\mathrm{Q}_{10 \%}$ maximum once every 10 years, $Q_{1 \%}$ - once every 100 years, and $Q_{0.2} \%$ - once every 500 years).

\begin{tabular}{cc}
\hline $\begin{array}{c}\text { Characteristic } \\
\text { Name }\end{array}$ & $\begin{array}{c}\text { Flow } \\
{\left[\mathbf{m}^{3} / \mathbf{s}\right]}\end{array}$ \\
\hline SNQ & 289 \\
\hline SSQ & 921 \\
\hline $\mathrm{Q}_{50 \%}$ & 2964 \\
\hline $\mathrm{Q}_{10 \%}$ & 5195 \\
\hline $\mathrm{Q}_{1 \%}$ & 8008 \\
\hline $\mathrm{Q}_{0.2 \%}$ & 9885 \\
\hline
\end{tabular}

After the commencement of works related to the Włocławek Barrage, systematic measurements of sediment transport in the lower section of the Vistula River began. The collected measuring material allowed for precise calibration of the sediment transport model. Additionally, the measurements carried out from 1895, in the region of the manmade mouth of the Vistula River into the Baltic Sea, were selected for the comparison. The volume of the lost bottom material in the period 1968-1995 in the region of Włocławek Barrage $(700 \mathrm{~km})$ is estimated at $7 \times 10^{5} \mathrm{~m}^{3} /$ year [2]. Total transport (bed load and suspended load) in the period 1971-1990 in Torun ( $\mathrm{km} \mathrm{734)} \mathrm{amounted} \mathrm{to} 7.72 \times 10^{5} \mathrm{~m}^{3} /$ year, while in the same period in Świecie $\left(\mathrm{km} \mathrm{712)}\right.$ it amounted to $1.1 \times 10^{6} \mathrm{~m}^{3} /$ year [16]. For comparison, the volume of accumulated material in the Vistula mouth $(\mathrm{km} \mathrm{940)}$ in the period 1970-2002, varied annually from $4 \times 10^{5}$ to $6 \times 10^{5} \mathrm{~m}^{3}$, on average $[17,18]$. This amount does not include the sediment volume accumulated in the Vistula estuary. Based on the movement of bottom forms (bed load) the sediment transport in the period 1971-1990 was estimated as $5.7 \times 10^{5} \mathrm{~m}^{3} /$ year in Torun and $7.5 \times 10^{5} \mathrm{~m}^{3} /$ year in Świecie [19].

\section{Results}

\subsection{Bathymetry Changes without Barrages-Scenario SO}

The MIKE 11 DHI [20] software package was selected for the analysis. Their hydrodynamic module is based on the solution of the de Saint-Venant one-dimensional system of equations. Thanks to a large simplification in the description of hydrodynamics, this approach enables modeling long river sections (river system) in a long-term perspective [21]. The construction and calibration of the hydrodynamic model was performed as part of the preliminary analysis of the Lower Vistula Cascade carried out by [7].

This hydrodynamic model describes the flow in the river section from Włocławek Barrage to the Vistula River mouth in the Baltic Sea $(266 \mathrm{~km})$. To set-up this model 456 bathymetric profiles, measured for the analysis of navigation conditions on the Vistula, were used $[6,14]$. As part of the model calibration, the roughness coefficients were selected, enabling the correct representation of water levels and flows along the entire modeled river section. For selected floods, an analysis of modeling accuracy was carried out. Calculations were performed using flow conditions at the upper boundary and water levels at the lower boundary. For comparison, water levels from selected hydrological stations of the State Flood Protection System were in use. The maximum error between modeled and measured water levels did not exceed $0.40 \mathrm{~m}$, which is considered a good result [6].

The Ackers-White formula [20] to describe the total transport (bed load and suspended load) was chosen. Calibration of the sediment transport intensity was carried out for the S0 scenario with simultaneous determination of bathymetry changes. This calculation did not cover the impact of temporary sea level fluctuations. A constant water level $(\mathrm{h}=0.0 \mathrm{~m}$ above mean sea level) was assumed at the lower limit of the model. At the upper limit of the modeled area, the time series for the period 2028-2078 (Figure 2) was assumed. 
The basic calibration parameter for the Ackers-White formula in the MIKE 11ST module is the sediment diameter. The tests of sediment samples taken from the bottom of the Vistula River show considerable diversity [14]. The median of the sediment ranges from $\mathrm{d}_{50}=0.3$ to $\mathrm{d}_{50}=0.7 \mathrm{~mm}$. For modeling purposes in [14], the authors assumed two diameters along the tested section of the Vistula River, i.e., $d_{50}=0.42 \mathrm{~mm}$ and $\mathrm{d}_{50}=0.47 \mathrm{~mm}$. From Babiński's [2] research, the sediments with a diameter of approx. $0.4 \mathrm{~mm}$ were the most common. Moreover, in the Korzeniewo section ( $\mathrm{km} \mathrm{868)} \mathrm{[22],} \mathrm{large} \mathrm{bottom} \mathrm{forms}$ were composed of sediment with $\mathrm{d}_{50}=0.4 \mathrm{~mm}$. In calculations, a uniform bottom sediment diameter was assumed. Searching sediment diameter for which calculated total transport would be closest to the measurements, was the goal of calculations. For the final calculations, the diameter of $\mathrm{d}_{50}=0.4 \mathrm{~mm}$ was adopted.

The calculated annual volumes of sediment transport for the subsequent years of the simulation show a high variability due to flow changes. When calculating the sediment transport for repeated flow periods (10-year time series repetition) one would expect similar transport rates. However, due to the bathymetry change and the adjustment of the bottom to the flow, the transport intensity with successive repetitions of the flow time series changes (Figure 3). The averaged value of transport from the entire forecast period is shown in a bold green line, while the measurements of transport intensity in specified locations discussed earlier are presented using squares and circles. A good agreement was obtained between the measured and modeled results of sediment transport; this result confirms the appropriate choice of the formula to describe the sediment transport. The assumption of a constant grain diameter allowed neglecting the influence of variability of this parameter on the modeling results of the bathymetry changes. At the same time, it was assumed that on the section from km 675 (Włocławek Barrage) to km 699, the bottom erosion is hardly observed. It is an area of clay and clay outcrops, and it is covered with boulders resulting from the erosion of sandy deposits [14]. The transport of sediments directly below the Włocławek Barrage was estimated based on changes in bathymetry; these changes extend to Torun ( $\mathrm{km} \mathrm{734).} \mathrm{For} \mathrm{this} \mathrm{reason,} \mathrm{the} \mathrm{value} \mathrm{of} \mathrm{sediment} \mathrm{transport}$ should be compared with the calculations for $\mathrm{km} 734$ of the Vistula River.

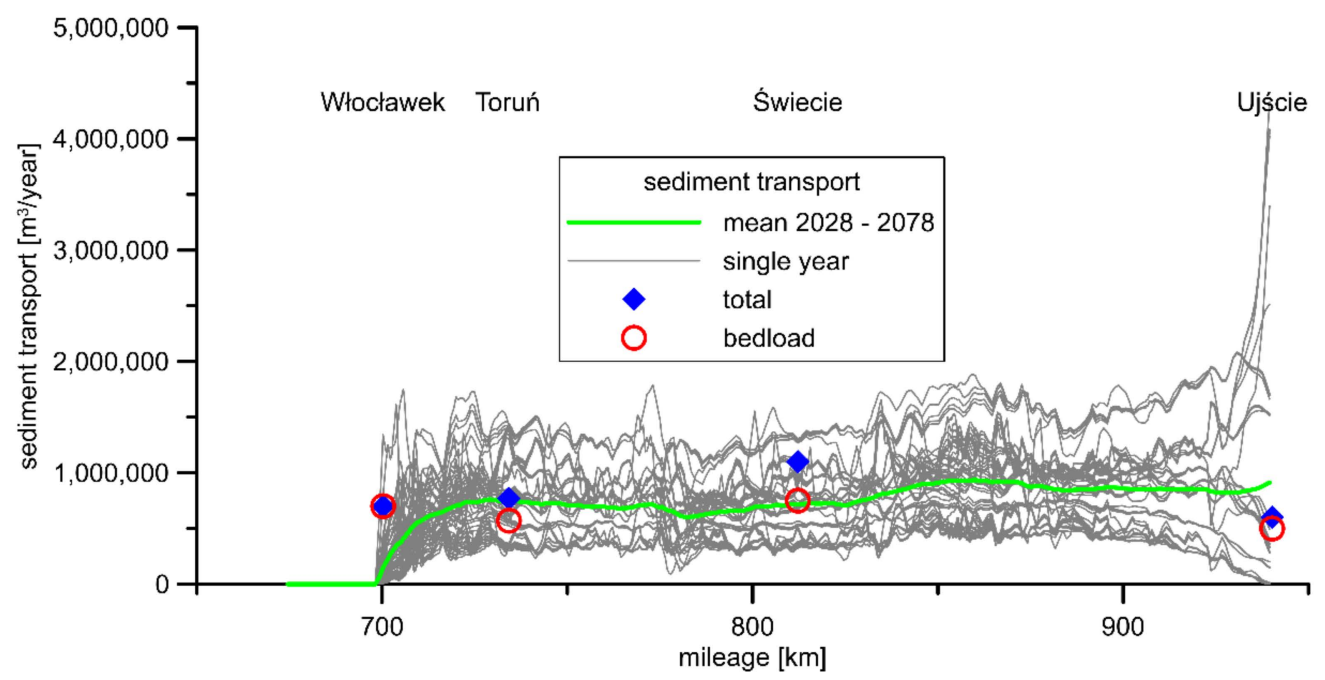

Figure 3. Calculated annual transport of sediments in the years 2028-2078 (set of thin grey lines) and averaged (green line) in the analyzed period according to the $\mathrm{S} 0$ scenario, compared to the measured values published in [2,17-19].

Calculations for S0 scenario for the analyzed section of the Vistula allowed determination of the natural changes in bathymetry (Figure 4a). There is no change in the bottom elevation in the area ( $\mathrm{km} \mathrm{675-699),} \mathrm{where} \mathrm{the} \mathrm{non-erodible} \mathrm{bottom} \mathrm{was} \mathrm{assumed.} \mathrm{However,}$ under some natural conditions, erosion can occur due to breaking off large pieces of clay from the bottom. Such a process causes local abrupt erosion. Unfortunately, modeling such 
a process is practically impossible in the adopted spatial range (almost $300 \mathrm{~km}$ of the river section) and time span (50 years). Bathymetry fluctuations up to $1 \mathrm{~m}$ in the period of the first 10 years of the simulation result from the adjustment of the bed system to the flow and transport of sediment. Below kilometer 700, an area of intensive bottom erosion begins, due to lack of continuity in sediment transport through the Włocławek Barrage and the bed armoring area. The rate of displacement of the erosion front is about $0.72 \mathrm{~km} /$ year; after 50 years, the erosion front will reach $\mathrm{km} 736$. This calculated value of the erosion front displacement rate is close to the observed value, i.e., $1.1 \mathrm{~km} /$ year of erosion below the Włocławek Barrage in the period 1968-1995 [2]. In the 50-year forecast, approx. $4 \mathrm{~m}$ bottom erosion can be expected; it is comparable to the observed values below Włocławek Barrage (Figure $4 b$ ).

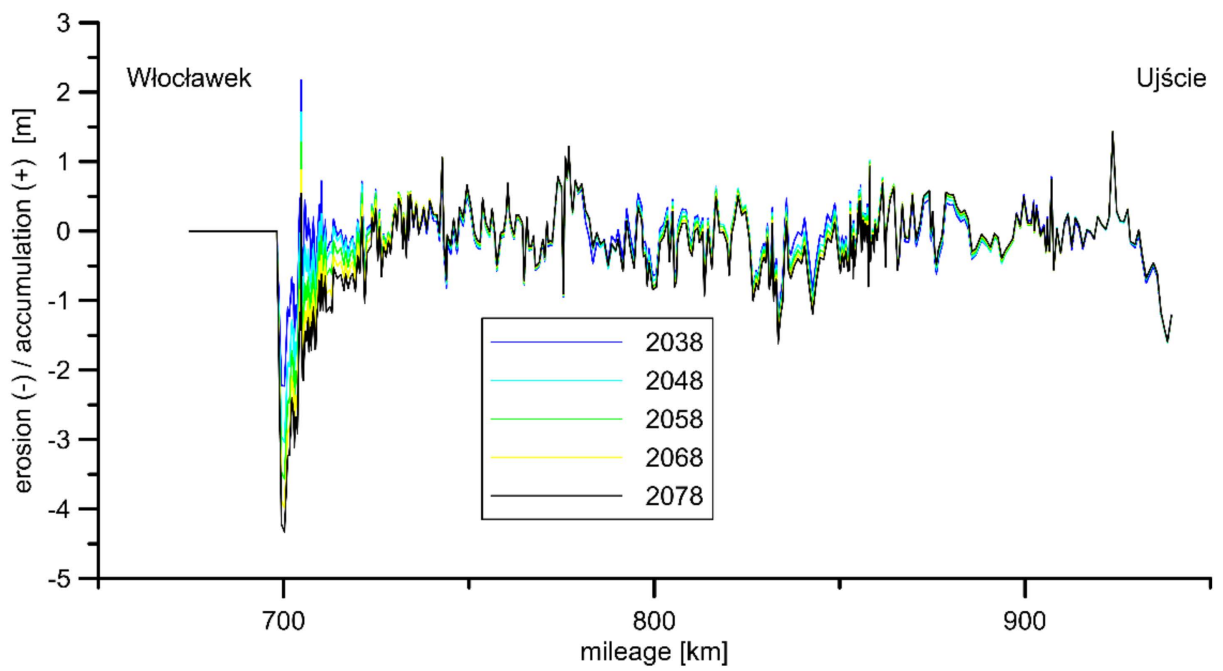

(a)

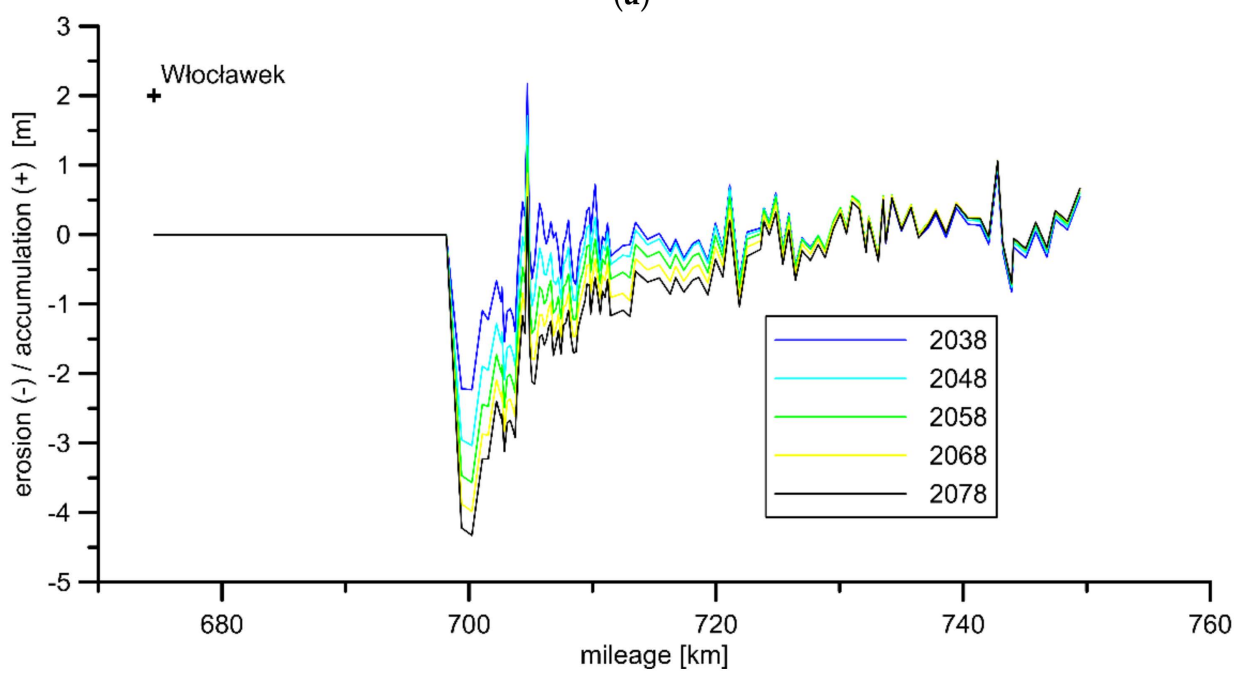

(b)

Figure 4. (a). Changes in bathymetry over time for the $\mathrm{S} 0$ scenario for the entire modeled section in the selected years. (b). Changes in bathymetry over time for the $\mathrm{S} 0$ scenario below the Włocławek Barrage.

The numerical model covers only the permanent Vistula riverbed; it does not include the accumulation cone where temporary outlet channels of variable geometry, length, and shape are formed [17]. Adopting a constant water level as the lower condition of the modeling area does not cause significant changes in bathymetry, except for the river mouth. 
In addition, the change in the bottom configuration results only from the flow; in the subsequent 10 -year period, the bottom shows no fluctuations.

\subsection{Impact of the Lower Vistula Cascade on Bathymetry Changes in the SII Scenario}

Constructing a system of barrages causes changes in a river flow. Flow velocity decreases in the dam reservoirs and similarly the transport of sediment [23]. Due to the lowland nature of the river, the designed cascade will have a strong impact on the water level for flows below SSQ (Figure 5). Flood flows will resemble conditions without a cascade [11].

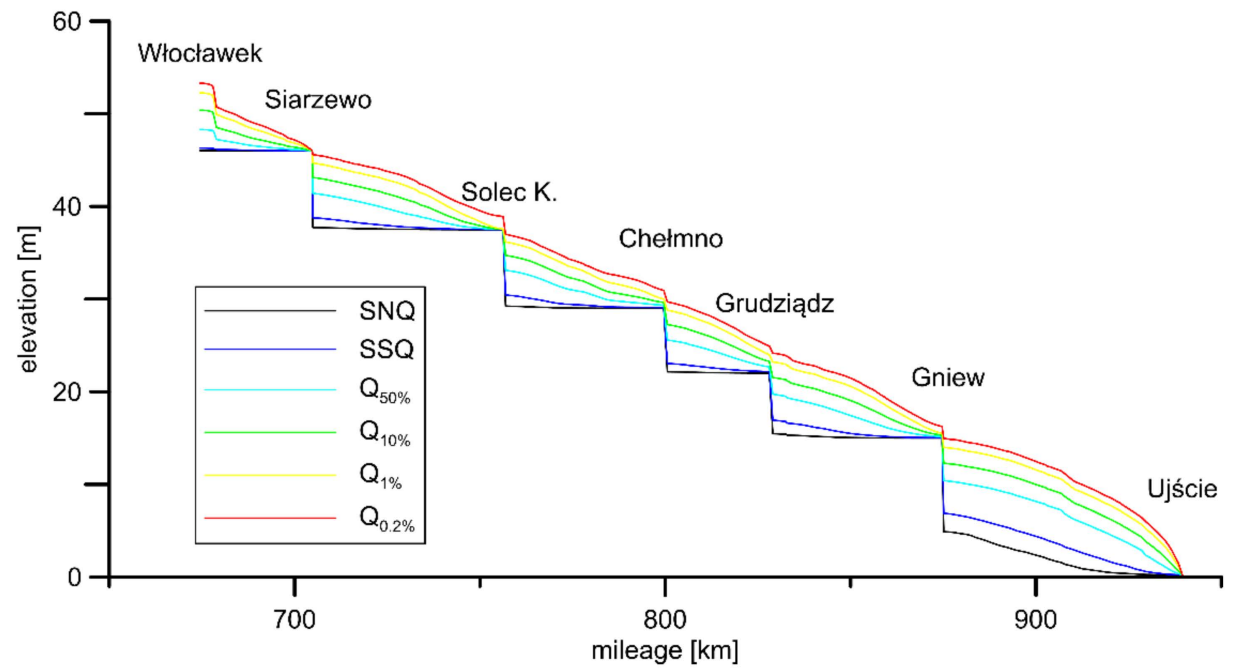

Figure 5. Position of the water levels in 2078 for the characteristic flow conditions after construction of the cascade according to SII scenario.

The one-dimensional model, which is MIKE11 [20], due to its structure, cannot reproduce the details of a dam structure; in particular, it concerns the water dissipation basin below a barrage. In engineering practice, it is assumed that water velocity below dissipation constructions will be close to the natural flow. For this reason, dissipation constructions of this type can be omitted at the modeling stage. The research of energy dissipation constructions is a separate issue and is subject to physical and numerical modeling.

The construction of the Siarzewo Barrage $(706 \mathrm{~km})$ in 2028 will result in the accumulation of up to $2 \mathrm{~m}$ of sediment in the reservoir before the dam and erosion below the dam reaching $3.5 \mathrm{~m}$ (Figure 6a). The erosion process will be stopped after the construction of the Solec Kujawski Barrage in 2052. The construction of the Gniew Barrage in 2034 will cause up to $2 \mathrm{~m}$ of sediment accumulated above the barrage and erosion up to $4 \mathrm{~m}$ below (Figure $6 \mathrm{~b}$ ). By 2078, the range of erosion will reach $44 \mathrm{~km}$, meaning about $1 \mathrm{~km} /$ year. Assuming the same rate of erosion, its front will reach the Vistula River mouth approximately 60 years after construction of the Gniew Barrage. Such a rapid movement of the erosion front and the anticipated deepening of the bottom will result in difficulties in the operation of river ports and locks. Strong erosion is also forecast below the Grudziadz Barrage. It is estimated that 38 years after the construction of this barrage, the bottom erosion will reach $3.4 \mathrm{~m}$ (approximately $0.10 \mathrm{~m}$ /year). Immediately above the Gniew Barrage, an accumulation of up to $2 \mathrm{~m}$ will occur. Erosion below successive barrages (Solec Kujawski, Grudziądz) will be smaller, reaching $2 \mathrm{~m}$. This is due to the presence of previously constructed barrages. The long period of time when the Siarzewo Barrage will work unsupported by a construction below (2028-2052) is reflected by strong erosion below the barrage, reaching up to $3.5 \mathrm{~m}$. 


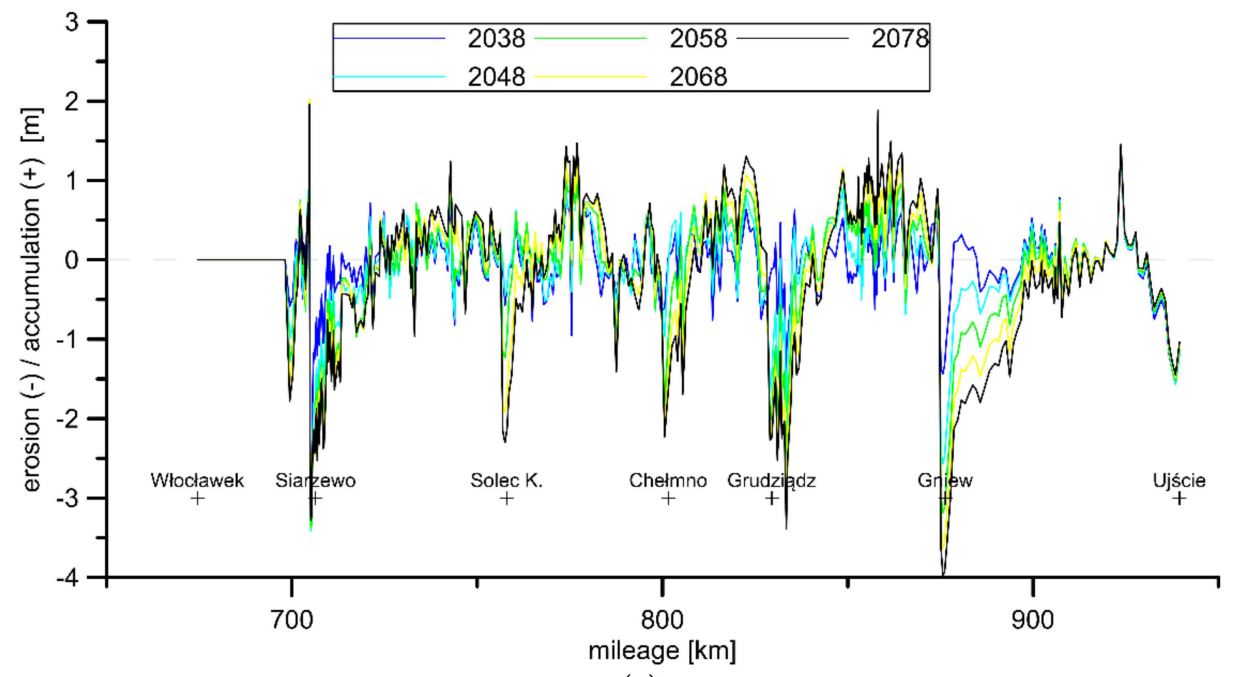

(a)

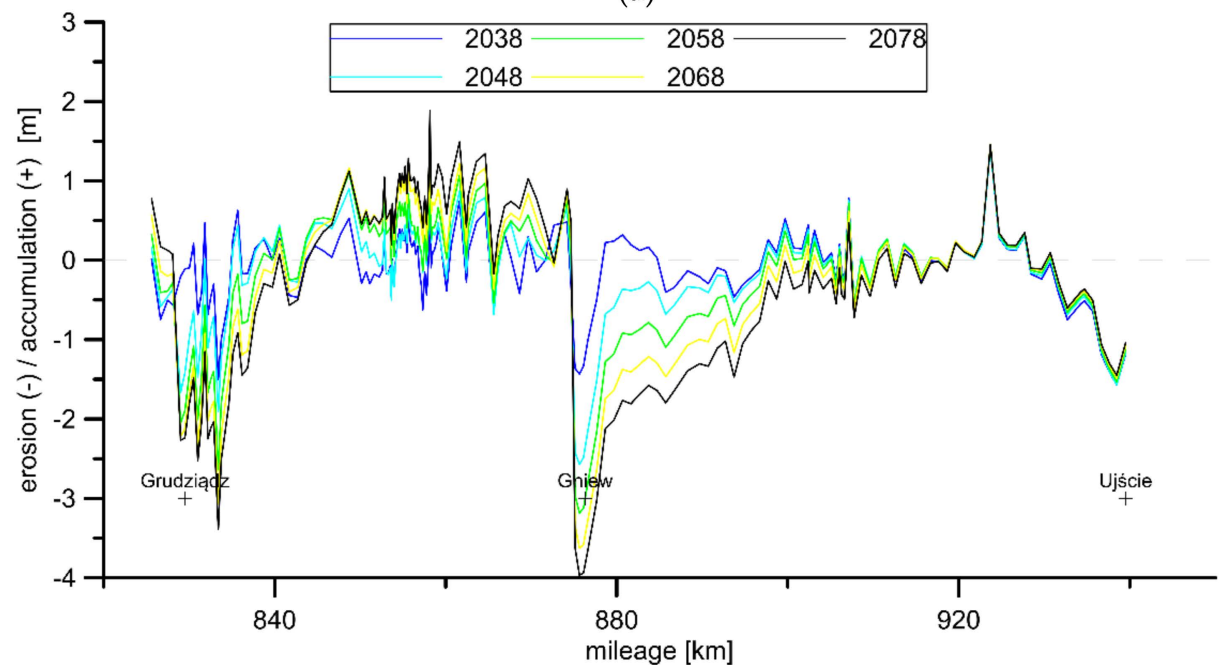

(b)

Figure 6. (a). The difference between the bathymetry calculated in the SII scenario and the initial bathymetry. (b). The difference between the bathymetry calculated in the SII scenario and the initial bathymetry for the lower part of the analyzed river section.

Such strong changes in the river depth after the construction of the cascade are unacceptable. For this reason, methods for sediment transfer within the cascade were searched.

\subsection{Identification of Flushing Flows}

Choosing the right time for sediment relocation is difficult. The generation of the flushing flow may be seen as necessary but undesirable from the point of view of river navigability or the operation of hydropower plants. Efficiency of sediment transport, and thus of flushing, increases with increasing flow [24]. The generation of artificially increased flow to improve navigation raises objections from the public as an interference in the ecosystem $[25,26]$. For this reason, floods exceeding $5000 \mathrm{~m}^{3} / \mathrm{s}$ were selected for the flushing process. In conditions of a high flow rate, water occupies the area between the flood embankments. Then flooding of sandbanks, inhabited by birds, resembles a natural process.

In the ten-year period used to create the hydrograph, such flows occurred five times. The total time provided for the flushing process equals 250 days over a 10-year period, giving 25 days per year, on average (Figure 7). Unfortunately, the long-term flow variability in the Vistula is not high and is not as repeatable as in other rivers, e.g., the Nile [27]; therefore, it is not possible to plan systematic annual flushing of the sediment. 


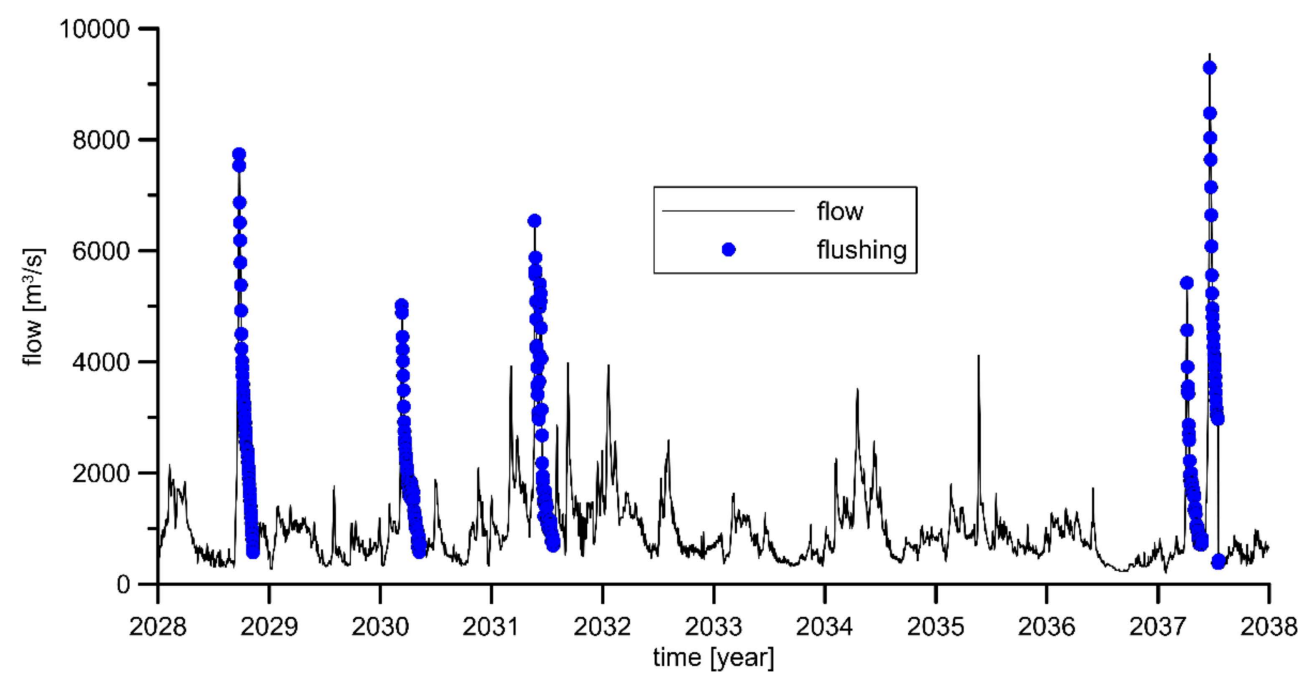

Figure 7. Exemplary flooding periods selected for the flushing process.

In the case of high flows, the difference between the lower and upper water levels is very small (Figure 5). The flushing procedure should allow leaving all spans of the weir open. The advantage of this solution is using the flood for the flushing process because at that time navigation is closed.

\subsection{Flushing Process}

Two flushing options were tested. The first option (WI) assumed a partial lowering of the water level in the reservoir, while the second (option WII) assumed a complete lowering of water level to the difference resulting from the bottom shape. Option WII shows the maximum efficiency of the flushing process. The first flushing after constructing of the Gniew Barrage will be discussed below. In the years following flushing, the differences in the shape of the bottom will be significant; thus, changes between options will occur. The flushing process was carried out using flooding with a maximum flow rate of $5420 \mathrm{~m}^{3} / \mathrm{s}$. This flow is slightly higher than the $\mathrm{Q}_{10 \%}$ flow, i.e., the one that should statistically occur once every 10 years (Figure 8).

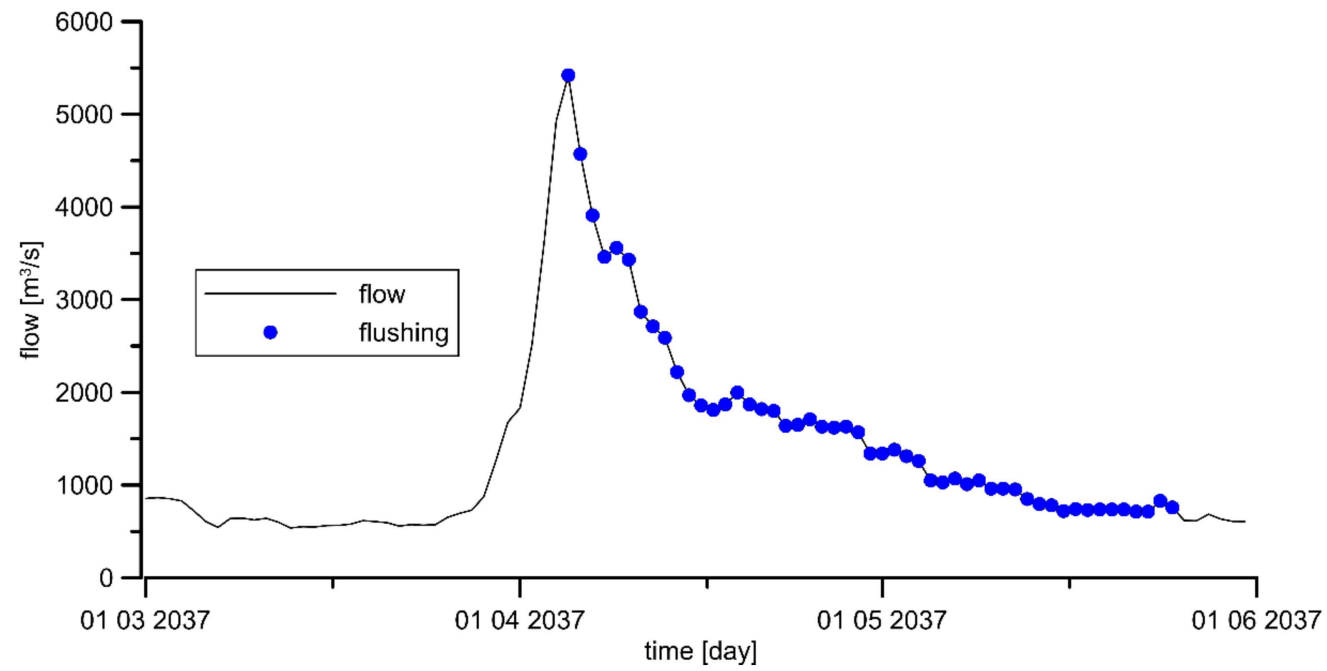

Figure 8. The first flooding used for the flushing process through the Gniew Barrage; solid line-flow through the barrage, points-days on which flushing is carried out.

In the flushing process, the rate of the water level lowering in the reservoir is very important [24]. In option WI, the difference between the upper and lower water level 
ranges from 0.9 to $0.6 \mathrm{~m}$, while in option WII from 0.2 to $0.05 \mathrm{~m}$. In option WI, the water level in the reservoir is slightly affected by the weir, while in option WII, the presence of the weir does not influence the water level in the reservoir (Figure 9). It is a very demanding assumption as to how to design such a barrage. Drastic reduction in the water level in the reservoir can be compared to the temporary removal of the dam.

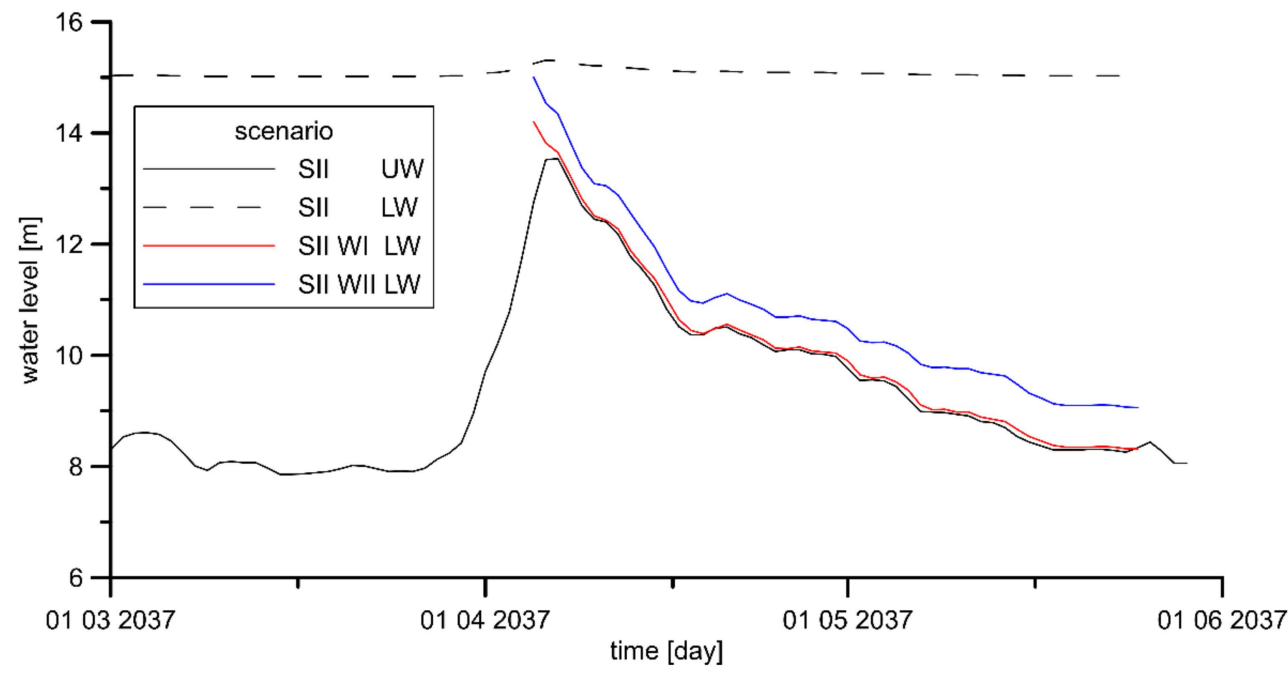

Figure 9. Location of the upper (UW) and lower water (LW) level for options WI and WII, during the flushing process.

A small difference in the position of the upper water level between options WI and WII (Figure 9), of the order of $0.6 \mathrm{~m}$ during flushing process, causes three times larger sediment transport (Figure 10). However, without lowering the water level in the reservoir, the sediment transport equals zero. This is consistent with observations of sediment transport during dam removal [28].

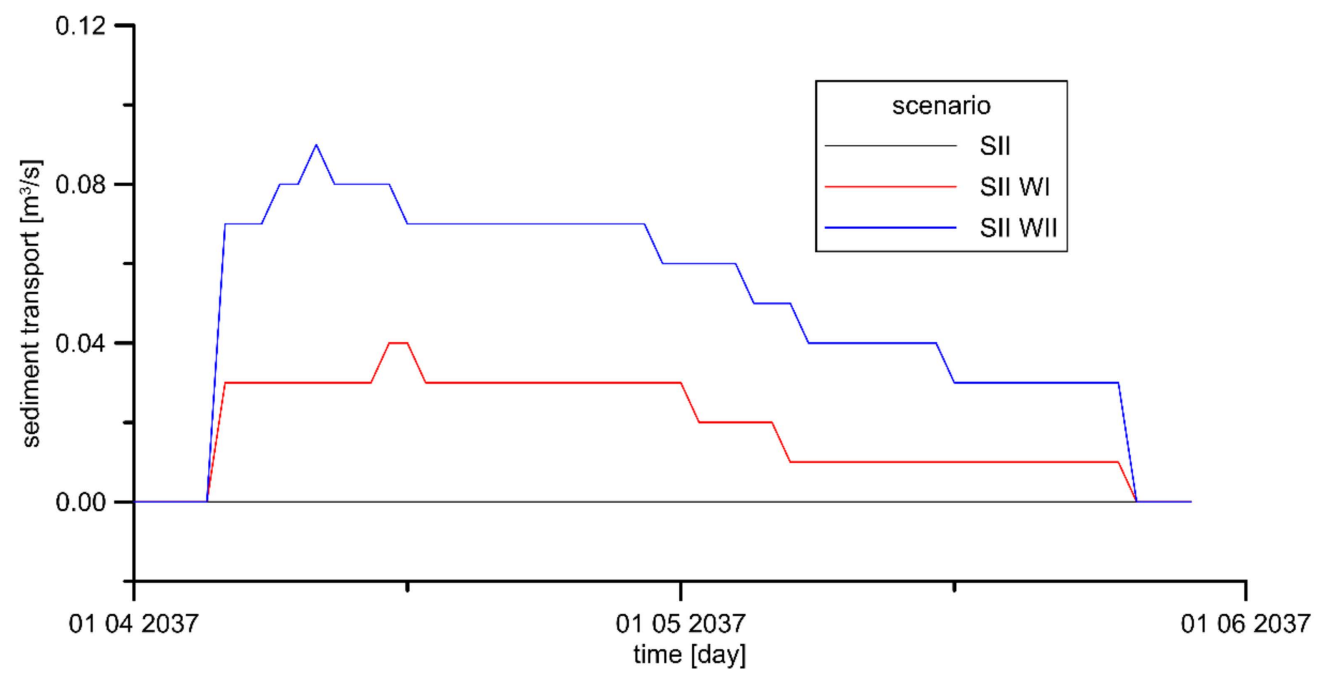

Figure 10. Transport of sediments through the Gniew Barrage in scenarios without flushing (SII) and with flushing (SII WI and SII WII).

As a result of flooding, in the absence of flushing, erosion occurs below the Gniew Barrage; for the WI flushing option, a small accumulation, of the order of $0.06 \mathrm{~m}$, is observed. However, for the WII option, the accumulation reaches $0.27 \mathrm{~m}$ (Figure 11). The changes in the bottom elevation above the barrage are also interesting. Without the flushing process, the bottom is stable, and no changes are observed. In the case of the flushing process, in 
both options, there is an increase in the bottom elevation; it indicates sediment transfer from the upper part of the reservoir towards the barrage.

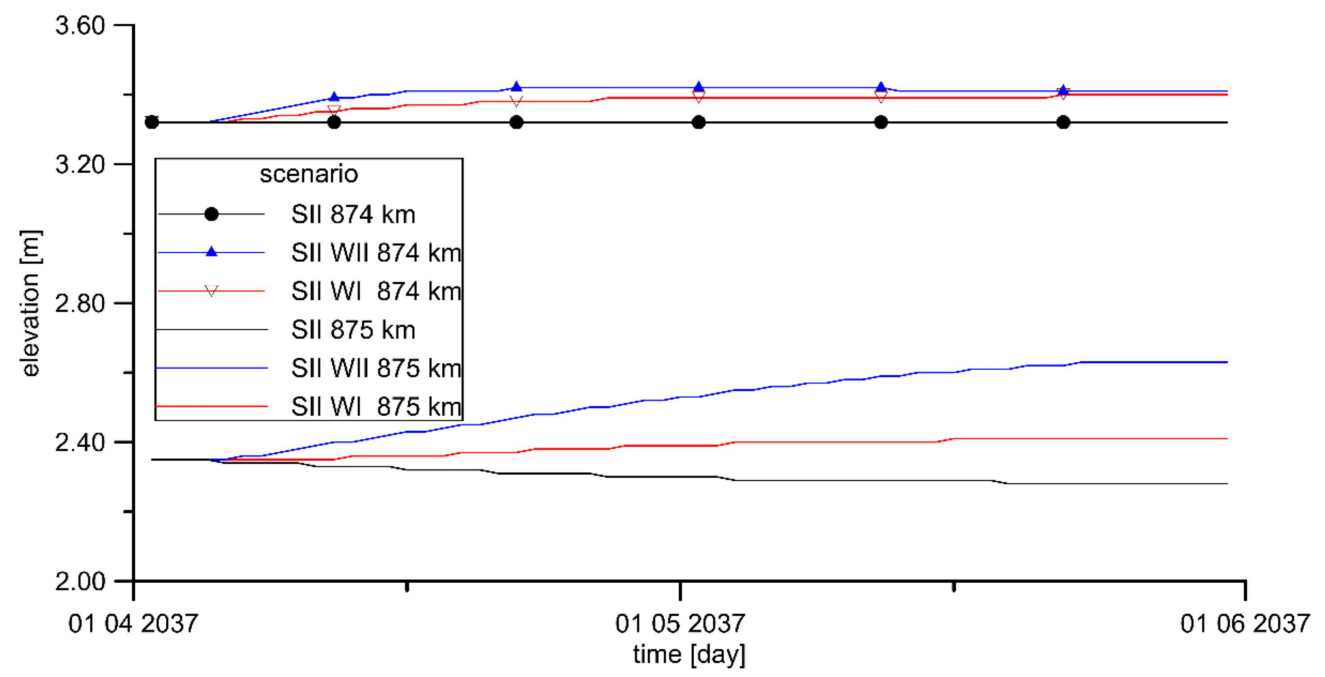

Figure 11. Changes in the bottom elevation for $\mathrm{km} 875.123$ and $\mathrm{km} 874.648$ for options without flushing and with flushing in options I and II for the first flushing period after construction of the Gniew Barrage.

Throughout the 50-year simulation period, differences between the flushing options increase (Figure 12). In the scenario without flushing, when the flooding passes, a small erosion slowdown is visible below the barrage. Only at the very end of the forecast period, after flooding (June 2077), does an accumulation of $0.15 \mathrm{~m}$ appear. For comparison, in the same period, the forecasted bathymetry change for the WI option is equal to $0.65 \mathrm{~m}$, and for the WII option- $1.5 \mathrm{~m}$. Changes in the bottom elevation in the range of $1.5 \mathrm{~m}$ are very large from an ecological point of view. However, these values are observed in the Vistula [18,19]. To minimize the fluctuations in bottom location, the flushing process should be carried out with higher frequency, e.g., with the use of smaller flooding events.

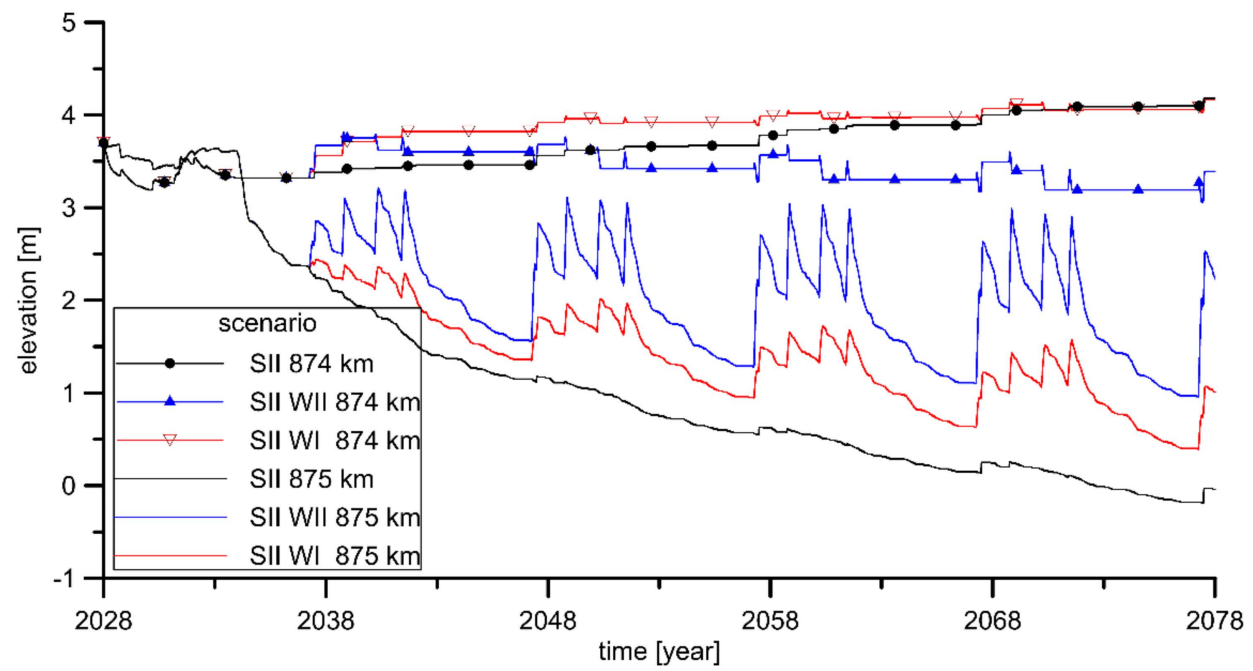

Figure 12. Changes in the bottom elevation for $\mathrm{km} 875.123$ and $\mathrm{km} 874.648$ for options without flushing and with flushing in option I and option II for a period of 50 years.

The analysis of changes in the riverbed position after a 50-year period for the entire modeled section shows that the flushing process, with the use of real flooding events, is a very effective method to maintain the continuity of sediment transport in the cascade 
(Figure 13a,b). At the same time, it indicates the importance of lowering the water level in the upper reservoirs for efficient flushing. Calculations were carried out for all time schedules (scenarios SI-SIV, see Table 2) for the construction of the Lower Vistula Cascade. The presented summery of the maximum erosion below the most critical barrage in Gniew is presented in Table 4. It shows that the use of the flushing process in each of the construction options minimizes the bottom erosion to an acceptable value of about $2 \mathrm{~m}$.

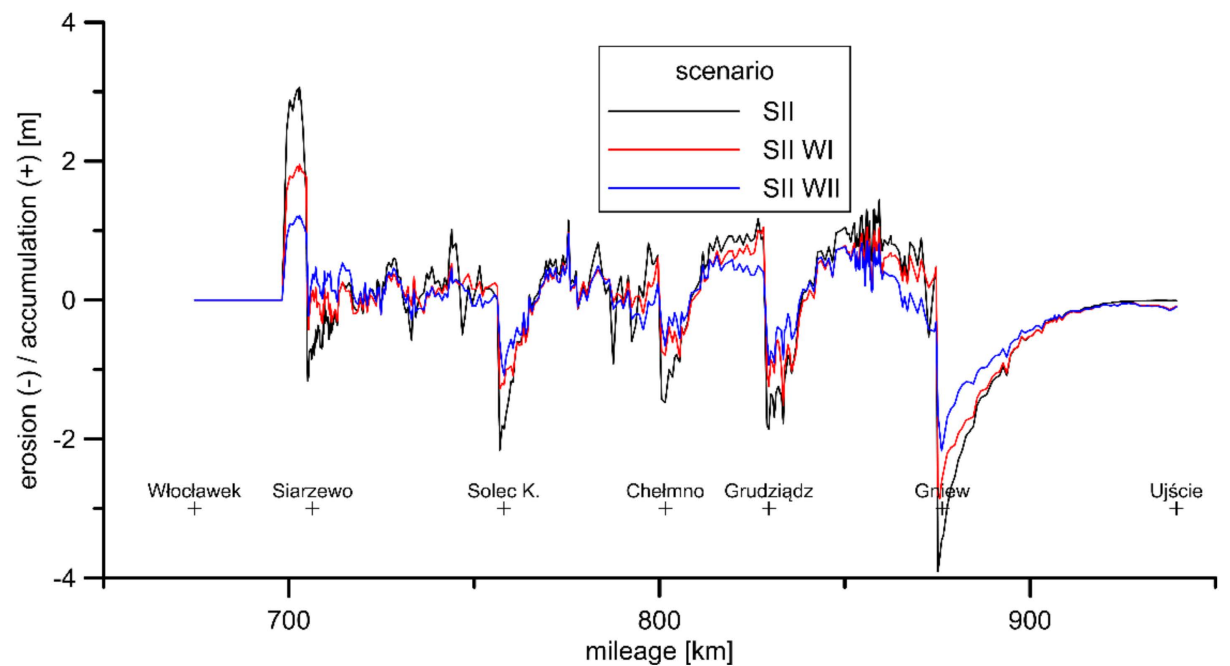

(a)

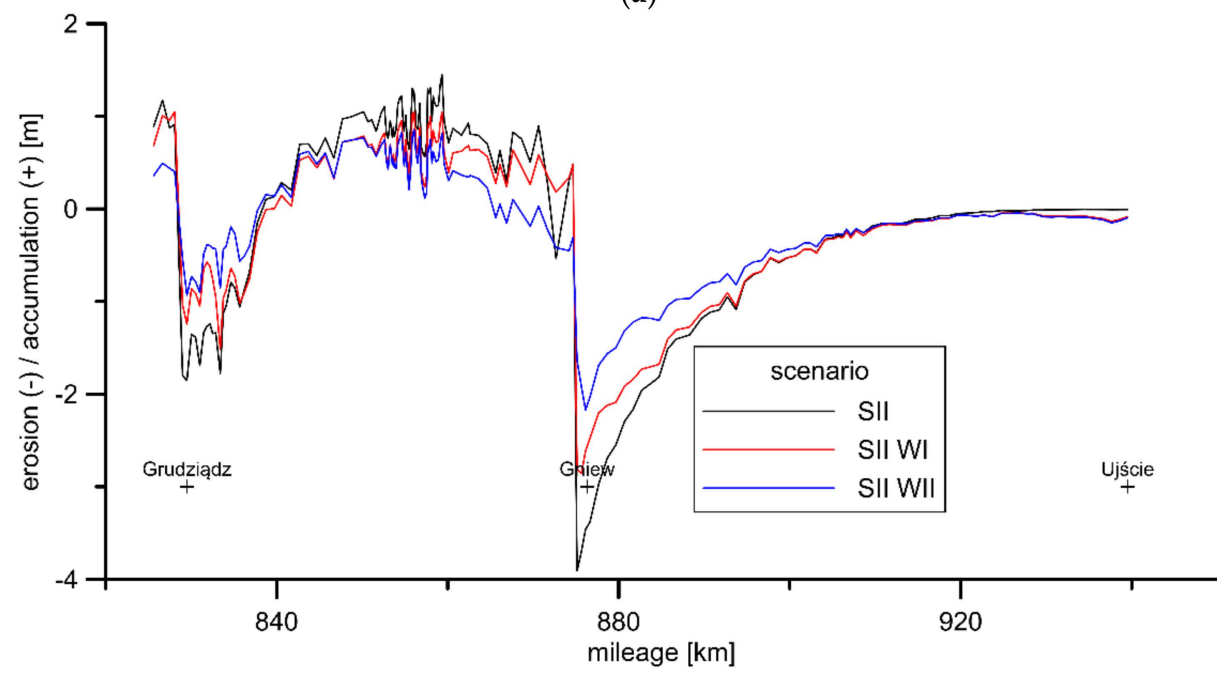

(b)

Figure 13. (a). Difference in the bottom elevation between Scenarios SII, SII WI, and SII WI for the whole cross-section. (b). Difference in the bottom elevation between Scenarios SII, SII WI, and SII WI for the lower part of the cross-section.

Table 4. The maximum erosion below the Gniew Barrage for scenarios SI-SIV.

\begin{tabular}{cccc}
\hline & W0 & WI & WII \\
\hline SI & $-3.21 \mathrm{~m}$ & $-2.50 \mathrm{~m}$ & $-1.83 \mathrm{~m}$ \\
\hline SII & $-3.90 \mathrm{~m}$ & $-2.85 \mathrm{~m}$ & $-2.16 \mathrm{~m}$ \\
\hline SIII & $-3.71 \mathrm{~m}$ & $-2.78 \mathrm{~m}$ & $-2.07 \mathrm{~m}$ \\
\hline SIV & $-3.90 \mathrm{~m}$ & $-2.75 \mathrm{~m}$ & $-2.11 \mathrm{~m}$ \\
\hline
\end{tabular}

As a result of the construction of the barrages, the water levels will change in the Vistula River. For low flows, the water level below the barrage is important. Lowering 
greater than planned may lead to difficulties in the operation of the navigation lock, fish passes, and operation of the hydroelectric power plant. For SNQ flow without a flushing process, the water level below the Gniew Barrage will drop by $2.42 \mathrm{~m}$. Conducting the flushing process, the SII WI option will reduce the water level by $2.06 \mathrm{~m}$, while for the SII WII option, the water level will drop by $1.52 \mathrm{~m}$ (Figure 14).

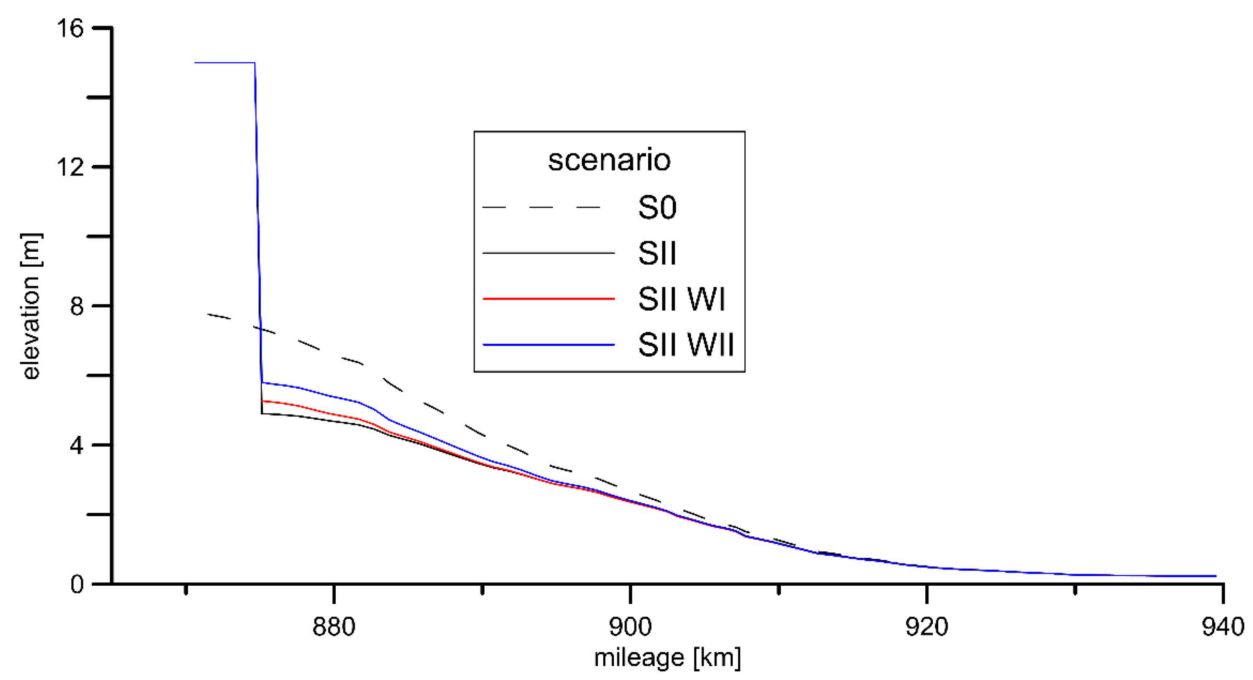

Figure 14. Difference in the bottom elevation between Scenarios S0 and SII, as well as options SII WI and SII WII for the SNQ flow for the entire cross section.

The accumulation of sediments above a barrage is important for flood flows, which leads to an increase in the water level and simultaneously an increase in the risk of flooding. For $\mathrm{Q}_{0.2 \%}$ flows, in the case of no flushing (option SII), the increase in the water level will reach $0.8 \mathrm{~m}$ at maximum, while for the SII WII option, it will be $0.45 \mathrm{~m}$ only (Figure 15).

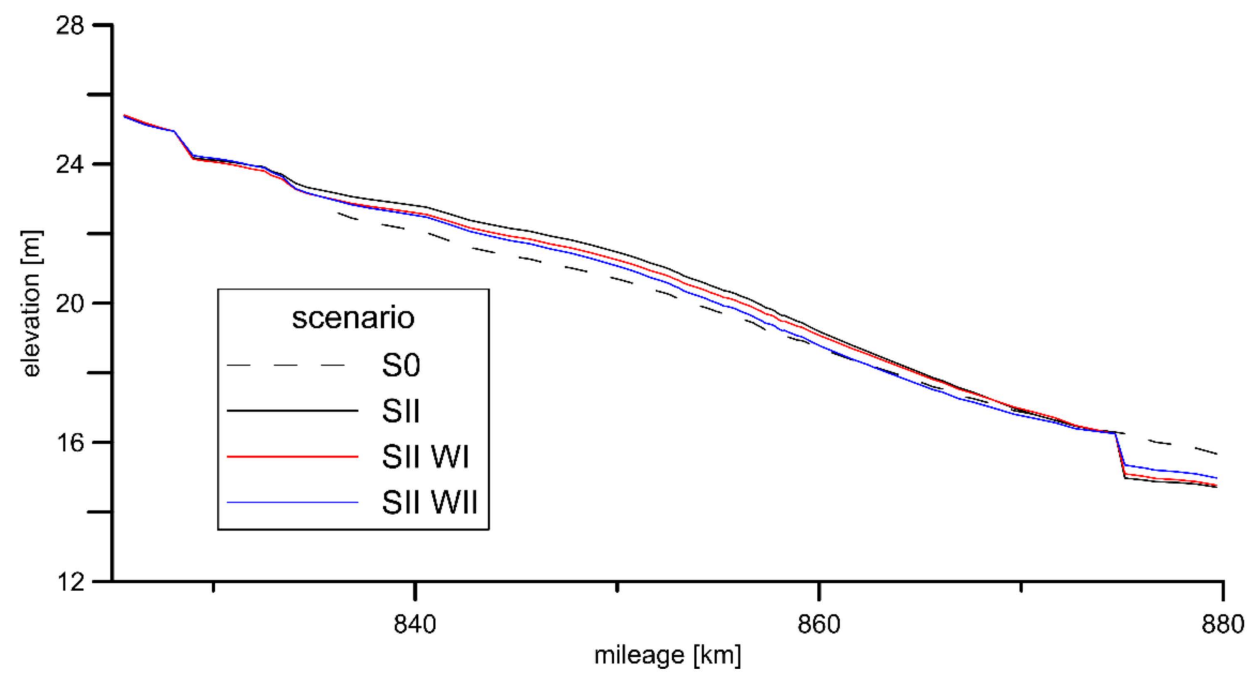

Figure 15. Difference in the bottom elevation between Scenarios S0 and SII, as well as options SII WI and SII WII for the $\mathrm{Q}_{0.2 \%}$ flow.

\section{Discussion and Conclusions}

Maintaining the continuity of sediment transport is very important from a technical and ecological point of view. Minimizing the bottom erosion below and accumulation above the barrage is important for the safety of barrage construction, navigation, and changes in groundwater level. Maintaining the sediment movement and the continuity of the bottom reconstruction is important for living organisms. 
In the 1960s, during the research and design studies of the Włocławek Barrage, the issue of sediment transport through the barrage was completely ignored. The Lower Vistula Cascade, currently under design, should provide the continuity of sediment transport. It is one of the priority issues to be solved within this project.

This paper presented an analysis of sediment transport over a 50-year period on the Vistula section from Włocławek to Ujście in the case of the construction of five barrages and without new barrages. According to plans, Siarzewo will be the first investment. Three optional time schedules for their construction were considered. Option II, in which, after the construction of the Siarzewo barrage, the next barrages will be built starting from the Gniew towards Siarzewo, was considered the most unfavorable. The 1D model using MIKE 11 was used for the analysis; it enabled the assessment of bottom changes in the analyzed section. The obtained results showed significant erosion, as high as $4 \mathrm{~m}$, below the barrages.

Since such a solution is unacceptable, a method allowing the sediment to pass through the water barrage was proposed. It has been proposed to use flows above $5000 \mathrm{~m}^{3} / \mathrm{s}$ to transfer sediment accumulated in the upper basin. Using the same sequence of historical flows used in the first part of analysis, the two flashing options were analyzed: I- without and II- with lowering the water level in the lower reservoir. Results have shown that, in the case of option II, it is possible to reduce the erosion to approx. $2 \mathrm{~m}$.

The presented simplified analysis allowed confirming the feasibility of the flushing process in maintaining the continuity of sediment transport. However, the proposed method requires solving some technical issues, such as the weir height or the shape of the upper reservoir basin.

The issue of sediment transport within the entire barrage, including the hydropower plant, as well as sediment transport within a single weir require additional analysis with the use of 3D numerical models [20] as well as physical models. In addition, the duration of the flushing process requires optimization. The assumptions made in the study presented above, especially flooding conditions, i.e., necessary discharge and duration, require further analysis. Based on the experiments carried out, it is obvious that starting the flushing process at the beginning of a flooding event, with the simultaneous lowering of the water level in the reservoir, will significantly extend the flushing time. At the same time, it will enable an increase in the emergency flood reserve by closing the weirs and leaving a certain volume of water in the reservoir.

The selection of flushing flow parameters, such as flow rate, duration, and frequency of flushing, will determine the effectiveness of this process. Indication of the flushing method and its duration will enable estimation of costs to be spent by the cascade administrator. In addition, the indication of a method ensuring the continuity of sediment transport will allow choice of the appropriate construction, to avoid the costs associated with their reconstruction.

Author Contributions: Conceptualization, J.B., M.R. and K.W. (Krzysztof Wrzosek); methodology, J.B., M.R., K.W. (Krzysztof Woś) and K.W. (Krzysztof Wrzosek); software, J.B.; validation, J.B., M.R. and K.W. (Krzysztof Wrzosek); formal analysis, J.B., M.R. and K.W. (Krzysztof Woś); investigation, J.B. and M.R.; resources, J.B. and K.W. (Krzysztof Wrzosek); data curation, J.B.; writing-original draft preparation, J.B.; writing-review and editing, M.R., K.W. (Krzysztof Woś) and K.W. (Krzysztof Wrzosek); visualization, M.R. and K.W. (Krzysztof Woś); supervision, K.W. (Krzysztof Woś); project administration, K.W. (Krzysztof Woś) and K.W. (Krzysztof Wrzosek); funding acquisition, K.W. (Krzysztof Woś) and K.W. (Krzysztof Wrzosek). All authors have read and agreed to the published version of the manuscript.

Funding: The APC was funded by State Water Holding Polish Waters KZGW/KN/2020/079.

Data Availability Statement: Hydrometric (river cross sections, rating curves) and galvanometric measurements used during the study were provided by a third party. Direct requests for these materials may be made to Polish National Water Management Authority (Wody Polskie https: //www.wody.gov.pl/). 


\begin{abstract}
Acknowledgments: The authors express their gratitude to Krzysztof Polak, Wojciech Skowyrski, and Przemysław Sobiesak for support and assistance in the preparation of the project and the materials provided.
\end{abstract}

Conflicts of Interest: The authors declare no conflict of interest.

\title{
References
}

1. George, M.W.; Hotchkiss, R.H.; Huffaker, R. Reservoir Sustainability and Sediment Management. J. Water Resour. Plan. Manag. 2017, 143, 04016077. [CrossRef]

2. Babiński, Z. Erosion and Accumulation Processes Below the Włoctawek Barrage, Their Consequences, and Impact on the Morphodynamics of the Planned Nieszawa Reservoir; IGiZP PAN: Torun, Poland, 1997; 46p. (In Polish)

3. Babiński, Z.; Habel, M. Hydromorphological conditions of the lower Vistula in the development of navigation and hydropower. Acta Energetica 2013, 2, 83-90. [CrossRef]

4. Damrat, M.; Zaborska, A.; Zajączkowski, M. Sediment from suspension and sediment accumulation rate in the River Vistula prodelta, Gulf of Gdańsk (Baltic Sea). Oceanologia 2013, 55, 937-950. [CrossRef]

5. Szydłowski, M.; Gąsiorowski, D.; Hakiel, J.; Zima, P.; Szymkiewicz, R. Analysis of the hydraulic effects of the Lower Vistula Cascade. Inżynieria Morska I Geotech. 2014, 5, 420-432. (In Polish)

6. Mykita, M.; Fedorczak, T.; Topiłko, J. Analysis of the Adaptation of the Vistula River in the Section from Włocławek to the Mouth of the Gulf of Gdańsk to the Large and Small Cascade-Modeling. In Stage III Volume I Annex 1 Tests on the Numerical Model; DHV Hydroprojekt-IMGW PIB: Warsaw, Poland, 2018; 122p. (In Polish)

7. JACOBS Halcrow Group Ltd. Feasibility Study for Comprehensive International Inland Waterway Management: E-40 for Vistula River between Gdansk and Warsaw, E-40 from Warsaw to the Poland-Belarus Border (Brest) and E-70 between the Vistula River and the Vistula Lagoon (Elblag); State Water Holding Polish Waters: Gdańsk, Poland, 2020; 3304p. (In Polish)

8. Wrzosek, K.; Sobiesak, P.; Sikorski, G. Characteristic technical solutions of the planned water barrages on the Vistula River at the E40 International Waterway section. Water Resour. 2021, 10, 23-32.

9. Woś, K.; Wrzosek, K. The Siarzewo Barrage Project as an example of a new quality in the realization of investments for the rational water resources management in Poland. HydropowerDams 2021, 2, 34-40.

10. Kondolf, G.M.; Gao, Y.; Annandale, G.W.; Morris, G.L.; Jiang, E.; Zhang, J.; Cao, Y.; Carling, P.; Fu, K.; Guo, Q.; et al. Sustainable sediment management in reservoir sand regulated rivers: Experiences from five continents. Earth's Future 2014, 2, 256-280. [CrossRef]

11. Kubrak, J.; Kiczko, A.; Kubrak, E. Case Study: Forecasting the Lower Vistula Bed Deformation without and with Development of Dam Cascade. Water 2021, 13, 2142. [CrossRef]

12. Woś, K. Directions of Activation of in-Land Shipping Activities in the Area of the Oder Estuary in the Conditions of Polish Integration with the European Union; Oficyna Wydawnicza "Sadyba": Warszawa, Poland, 2005; 214p. (In Polish)

13. ARUP. Ensuring Public Safety in the Area of the Włoctawek Dam with Water Energy and Improving the Potential of Aquatic and Dependent Water Ecosystems; Technical Report; National Water Management Authority (KZGW): Warsaw, Poland, 2012. (In Polish)

14. Kubrak, J.; Kiczko, A. Analysis of the Adaptation of the Vistula River in the Section from Włocławek to the Mouth of the Gulf of Gdańsk to the Large and Small Cascade-Modeling. In Stage III Volume I appendix 2a Investigation of Erosion Processes on Numerical Models, DHV Hydroprojekt; IMGW PIB: Warsaw, Poland, 2018; 135p. (In Polish)

15. ISOK. Project Report-Task 1.3.2-Data Preparation Hydrological Range Necessary for Hydraulic Modeling-Annex 1; MGW PIB: Warsaw, Poland, 2013; 95p. (In Polish)

16. Babiński, Z. Transport of suspended and bed load of the lower Vistula during the exploitation of the Włocławk barrage. Przeglad Geogr. 1994, 3-4, 285-307. (In Polish)

17. Pruszak, Z.; Szmytkiewicz, M. Vistula Delta, General Mechanisms of Formation of River Deltas and Estuaries; IBW PAN: Gdańsk, Poland, 2015; 148p. (In Polish)

18. Lisimenka, A.; Kubicki, A. Bedload transport in the Vistula River mouth derived from dune migration rates, southern Baltic Sea. Oceanologia 2018, 61, 384-394. [CrossRef]

19. Babiński, Z. Contemporary Channel Processes of the Lower Vistula, Prace Geogr; IGiZP PAN: Wrocław-Warsaw-Kraków, Poland, 1992; Volume 157, 171p. (In Polish)

20. DHI; MIKE 11. A Modeling System for Rivers and Channels. User Guide. Available online: https://manuals.mikepoweredbydhi. help $\backslash$ T1 $\backslash$ textgreater\{\}MIKE11 (accessed on 2 February 2021).

21. Ngoc, T. Assessing the Effects of Upstream Dam Developments on Sediment Distribution in the Lower Mekong Delta, Vietnam. J. Water Resour. Prot. 2017, 9, 822-840. [CrossRef]

22. Robakiewicz, M.; Sobczak, Ł. The Influence of River Training on Hydrodynamics and Morphological Changes in Open Channel Flow-the Example of the Lower Vistula River; Publications of the Institute of Geophysics; Polish Academy of Sciences; Water Resources E-5: Warsaw, Poland, 2005; Volume 387, pp. 149-177.

23. Hutter, K.A. Tutorial on Prograding and Retrograding Hypo- and Hyper-Pycnal Deltaic Foramations into Quiescent Ambients. In: Contributions on Sediment Transport. In Berichte des Lehrstuhls und der Versuchsanstalt für Wasserbau und Wasserwirtschaft der TU München; TU-Munich: Munich, Germany, 2013; Volume 127, pp. 1-80. 
24. Reisenbüchler, M.; Bui, M.D.; Skublics, D.; Rutschmann, P. Sediment Management at Run-of-River Reservoirs Using Numerical Modelling. Water 2020, 12, 249. [CrossRef]

25. Reckendorfer, W.; Badura, H.; Schütz, C. Drawdown flushing in a chain of reservoirs-Effects on grayling populations and implications for sediment management. Ecol. Evol. 2018, 9, 1437-1451. [CrossRef] [PubMed]

26. Jurszo, R. Over 420 bird nests have been destroyed and 5 million fish killed will help to win the legal battle against the perpetrators. Available online: https:/ / oko.press / zniszczono-ponad-420-gniazd-ptakow-i-zabito-5-mln-ryb-pomoz-wygrac-batalie-prawnaze-sprawcami / (accessed on 28 November 2021). (In Polish).

27. Betrie, G.D.; Mohamed, Y.A.; van Griensven, A.; Srinivasan, R. Sediment management modelling in the Blue Nile Basin using SWAT model. Hydrol. Earth Syst. Sci. 2011, 15, 807-818. [CrossRef]

28. Cheng, F.; Granata, T. Sediment transport and channel adjustments associated with dam removal: Field observations. Water Resour. Res. 2007, 43, 1-14. [CrossRef] 